\title{
Mechanism of Calcium Sulphate on the Aggregation and Growth of Ferronickel Particles in the Self-Reduction of Saprolitic Nickel Laterite Ore
}

\author{
Guihua Hang ${ }^{1,2,3}$, Zhengliang Xue ${ }^{1,2,3, *}$, Jinghui Wang ${ }^{1,2,3}$ and Yingjiang $\mathrm{Wu}^{1,4}$ \\ 1 State Key Laboratory of Refractories and Metallurgy, Wuhan University of Science and Technology, \\ Wuhan 430081, China; hangguihua1987@163.com (G.H.); jh_wangxx19@163.com (J.W.); \\ wuyingjiang04@163.com (Y.W.) \\ 2 Key Laboratory for Ferrous Metallurgy and Resources Utilization of Ministry of Education, Wuhan \\ University of Science and Technology, Wuhan 430081, China \\ 3 Hubei Provincial Engineering Technology Research Center of Metallurgical Secondary Resources, \\ Wuhan 430081, China \\ 4 WISDRI Engineering and Research Incorporation Limited, Wuhan 430223, Hubei, China \\ * Correspondence: xuezhengliang@wust.edu.cn; Tel.: +86-027-68862779
}

Received: 7 March 2020; Accepted: 24 March 2020; Published: 25 March 2020

\begin{abstract}
Saprolitic nickel laterite is characterized by relatively low iron and nickel contents. Iron and nickel oxides are reduced to form fine ferronickel particles that disperse and embed in silicates in the reduction process, limiting the application of magnetic separation to extract ferronickel. Additives are applied to promote the aggregation and growth of ferronickel particles, then the large ferronickel particles will be separated by fine grinding and recovered via magnetic separation. Calcium sulphate is considered to be capable of increasing the size of ferronickel particles considerably. Due to the decomposition of calcium sulphate in the reduction process, the mechanism of calcium sulphate on the aggregation and growth of ferronickel particles should be conducted studied in-depth. The current work explores the effects of calcium sulphate, elemental sulphur, and calcium oxide on the formation of ferronickel particles in a saprolitic nickel laterite ore. The results showed that the formation of an Fe-FeS eutectic and the mineral structure transformation contributed by calcium oxide were all conducive to the mass transfer of ferronickel particles in gangue, ferronickel particles aggregated and grew up at the boundary between the hole and the gangue. The self-reduction, fine grinding, and magnetic separation of nickel laterite ore in the presence of three types of additive were examined. Nickel laterite ore with $7.88 \mathrm{wt} \%$ coal, $12 \mathrm{wt} \%$ calcium sulphate reduced at $1200{ }^{\circ} \mathrm{C}$ for $30 \mathrm{~min}$, a ferronickel concentrate of $\mathrm{Ni} 8.08 \mathrm{wt} \%$, and Fe $79.98 \mathrm{wt} \%$ was obtained at a nickel and iron recovery of $92.6 \%$ and $79.9 \%$, respectively.
\end{abstract}

Keywords: nickel laterite ore; calcium sulphate; aggregation and growth; self-reduction; magnetic separation

\section{Introduction}

The annual global demand for nickel has increased tremendously due to its numerous applications, especially advantageous for the production of stainless steel, alloys, batteries, and catalysts [1-6]. In the last decade, with the continuous depletion of nickel sulfide, increasing attention has been paid to nickel laterite ore [7-13]. Nickel laterite deposits are classified into two distinct types: limonitic deposits found in the surface layer while the bottom layer is referred to as saprolitic deposits [14]. For saprolitic laterite ore, nickel and iron are difficult to concentrate by physical beneficiation due to the low nickel and iron content [15] and isomorphic goethite or serpentine crystalline structure [9]. Self-reduction of 
this type of ore at moderate temperatures to form a ferronickel alloy, which will be separated from the gangue by magnetic separation, is a useful method to obtain a ferronickel concentrate [3,16-18]. Because the fine ferronickel particles disperse and embed in gangue, effective upgrading by magnetic separation processes is challenging.

An increasing number of additives are employed in reduction roasting, such as chlorides, sulphur, and sulphates, alkali oxides, fluorides, sodium carbonate, and sodium hydroxide [19]. Additives contribute to the aggregation and growth of ferronickel particles [20-31]. Sulphur promotes the aggregation and growth of ferronickel particles by reducing the surface tension of ferronickel particles, and the formation of an $\mathrm{Fe}-\mathrm{FeS}$ eutectic facilitates the aggregation of ferronickel particles during reduction, the mechanism of sulphates on the aggregation and growth of ferronickel particles is consistent of sulphur [20,22-27,32-35]. Saprolitic ore has a high content of silica, while alkali oxides contribute to liquid phase by reacting with silica, which is conducive to mass transfer [19]. Sodium carbonate are able to enhance the reduction and beneficiation of nickel [36]. Calcium fluoride $\left(\mathrm{CaF}_{2}\right)$ can promote the aggregation and growth of ferronickel particles by reducing the surface tension of ferronickel alloy in the reduction roasting process [37]. Furthermore, additives are also employed in other process such as recycling iron in the process of recycling valuable metals [38] and the reduction of red mud [39].

Calcium sulphate $\left(\mathrm{CaSO}_{4}\right)$ decomposes to sulphur $\left(\mathrm{S}_{2}\right)$ and calcium oxide $(\mathrm{CaO})$ in a reduction atmosphere [35]. Troilite (FeS) is generated by the reaction of sulphur with iron or iron oxides, then $\mathrm{FeS}$ reacts with $\mathrm{Fe}$ to form $\mathrm{Fe}-\mathrm{FeS}$ eutectic, which intensifies the process of metal ions mass transfer $[20,21,23,35]$. An appropriate amount of $\mathrm{CaO}$ contributed to liquid generation, which favors the transfer of ferronickel in gangue [15]. For limonitic laterite ore, Zhu and co-workers found that the average particle size increased from $6.9 \mu \mathrm{m}$ to $17.8 \mu \mathrm{m}$, attributing this to an addition of $3 \mathrm{wt} \% \mathrm{CaSO}_{4}$ [35]. In another work, an increase of the average particle size from $1.21 \mu \mathrm{m}$ to $2.78 \mu \mathrm{m}$ with increasing the sulphur dosage from $0 \mathrm{wt} \%$ to $6 \mathrm{wt} \%$ [20]. The effect of calcium sulphate on ferronickel particles is greater than that of sulphur, the results investigated that the mechanism of calcium sulphate on the aggregation and growth of ferronickel particles maybe not merely attributed to sulphur. Furthermore, the effect of calcium sulphate on ferronickel particles in saprolitic laterite ore will be worthy of attention.

The present work aimed to further investigate the mechanism behind calcium sulphate on the aggregation and growth of the ferronickel particles in the self-reduction of a saprolitic laterite ore. Calcium sulphate, sulphur (the dosage of the sulphur addition was the sulphur content of calcium sulphate), and calcium oxide (the dosage of the calcium oxide addition was the calcium oxide content of calcium sulphate) were used to explore the effects on the formation of ferronickel particles, respectively. The average particle size and distribution of ferronickel particles in the presence of the three additives were analysed by ImageJ software (ImageJ v1.8.0, NIH, Bethesda, MD, USA), and the phase and microstructure transformation of nickel laterite ore in the reduction process was investigated using X-ray diffraction analysis (XRD) and scanning electron microscopy with X-ray energy dispersive spectrum (SEM-EDS). Of particular interest were the effects of the three types of additives on the grade and recovery of the ferronickel concentrate which was obtained by magnetic separation.

\section{Materials and Methods}

\subsection{Raw Materials}

The ore used for all of the experiments was a saprolitic laterite ore from Sulawesi Island, Indonesia. The raw ore was dried at $110^{\circ} \mathrm{C}$ for $4 \mathrm{~h}$, followed broken by a jaw crusher and ground by a centrifugal grinding machine to 100 mesh. Table 1 provides the chemical compositions of the ore as determined by X-ray fluorescence spectrometry (XRF). The silica to magnesia ratio is 2.83 . The average nickel and iron contents are $1.4 \mathrm{wt} \%$ and $16.18 \mathrm{wt} \%$, respectively. X-ray diffraction (XRD) analysis (Figure 1) shows that the crystalline phases of the nickel laterite ore mainly consisted of quartz $\left(\mathrm{SiO}_{2}\right)$, serpentine 
$\left(\mathrm{Mg}_{3} \mathrm{Si}_{2} \mathrm{O}_{5}(\mathrm{OH})_{4}\right)$, chlorite $\left(\mathrm{Ni}_{3} \mathrm{Si}_{2} \mathrm{O}_{5}(\mathrm{OH})_{4}\right)$, goethite $(\mathrm{FeO}(\mathrm{OH}))$, and lizardite $\left((\mathrm{Mg}, \mathrm{Fe})_{3} \mathrm{Si}_{2} \mathrm{O}_{5}(\mathrm{OH})_{4}\right)$. The nickel is associated with silicate in the form of chlorite.

Table 1. Compositions of nickel laterite ore (dry basis) used in the current work ( $\mathrm{wt} \%)$.

\begin{tabular}{ccccccccccccc}
\hline Component & $\mathbf{N i}$ & $\mathrm{TFe}$ & $\mathbf{F e O}$ & $\mathrm{Fe}_{2} \mathrm{O}_{3}$ & $\mathbf{C a O}$ & $\mathbf{A l}_{2} \mathbf{O}_{3}$ & $\mathrm{SiO}_{2}$ & $\mathbf{M g O}$ & $\mathbf{P}$ & $\mathbf{S}$ & $\mathbf{C r}$ & $\mathbf{O t h e r s}$ \\
\hline Nickel Laterite Ore & 1.40 & 16.18 & 0.53 & 22.52 & 0.84 & 2.65 & 41.35 & 14.59 & 0.008 & 0.012 & 1.62 & 14.48 \\
\hline
\end{tabular}

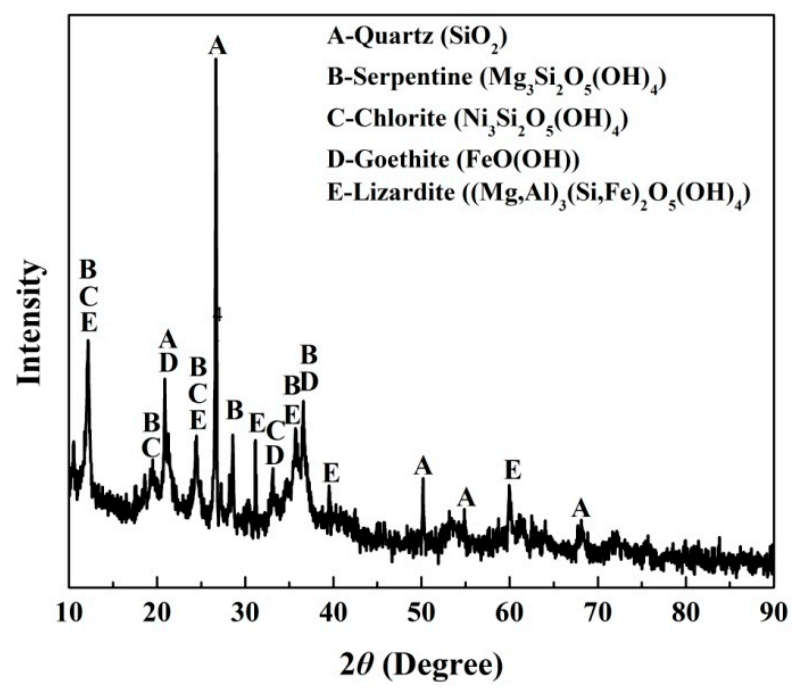

Figure 1. X-ray diffraction (XRD) analysis of nickel laterite ore.

Anthracite was used as the reductant in this study and ground to a size of -100 mesh for use. The industrial analysis of the anthracite showed that it contained $82.76 \mathrm{wt} \%$ fixed carbon, $5.28 \mathrm{wt} \%$ volatiles, $6.82 \mathrm{wt} \%$ ash, $5.14 \mathrm{wt} \%$ moisture, and $0.60 \mathrm{wt} \%$ total sulphur. Calcium sulphur $\left(\mathrm{CaSO}_{4}\right)$, sulphur $(\mathrm{S})$ and calcium oxide $(\mathrm{CaO})$ used in the study are of chemical grade.

\subsection{Experimental Methods}

Ground nickel laterite ore, coal powder, and additives were uniformly mixed in a certain proportion. The coal addition was $7.88 \mathrm{wt} \%$, calcium sulphate additions in the range of $0-16 \mathrm{wt} \%$, sulphur additions in the range of $0-3.96 \mathrm{wt} \%$, and calcium additions ranging from $0-6.6 \mathrm{wt} \%$, the required dosage of all additives with a balanced amount of nickel laterite ore sample. A total mixtures mass of $25 \mathrm{~g}$ was wetted with an appropriate amount of water and subsequently compacted at $6000 \mathrm{psi}$ into a cylindrical sample with a diameter of $20 \mathrm{~mm}$ and an approximate height of $30 \mathrm{~mm}$. Samples were dried at $110{ }^{\circ} \mathrm{C}$ before high-temperature reduction experiments.

The reduction experiments were conducted in a $25 \mathrm{~kW}$ high-temperature carbon tube furnace. Samples were charged into a corundum crucible and held for $30 \mathrm{~min}$ after the temperature reached the specified operating temperature of $1200^{\circ} \mathrm{C}$ under a nitrogen atmosphere. Reduced samples were quenched by quickly immersing them in water and then dried at $110{ }^{\circ} \mathrm{C}$ for subsequent detection and magnetic separation.

The reduced sample with a total mass of $15 \mathrm{~g}$ was ground by a centrifugal grinding machine for $12 \mathrm{~min}$. The slurry was separated into magnetic product and nonmagnetic product using wet magnetic separation with a magnetic field intensity of $0.1 \mathrm{~T}$. Finally, the obtained magnetic product was ferronickel concentrate. The compositions of ferronickel concentrate were tested and the corresponding nickel and iron recoveries were calculated per Equation (1), and the compositions of slag were calculated mass balance calculation in Equation (2):

$$
\eta_{(F e, N i)}=\left(\frac{\mathrm{m}_{1} \beta_{(F e, N i)}}{\mathrm{m}_{0} \alpha_{(F e, N i)}}\right) \times 100 \%
$$




$$
\lambda=\left(\frac{\mathrm{m}_{0} \alpha-\mathrm{m}_{1} \beta}{\mathrm{m}_{0}-\mathrm{m}_{1}}\right) \times 100 \%
$$

where $\eta$ is the nickel or iron recovery, $\lambda$ is the content of each element in slag, $\mathrm{m}_{1}$ is the mass of the ferronickel concentrate, $\mathrm{m}_{0}$ is the mass of the slurry, $\beta$ is the content of each element in ferronickel concentrate, and $\alpha$ is the content of each element in slurry.

\subsection{Analytical Methods}

The reduced samples were ground into fine powder for XRF and XRD analysis. The chemical compositions were determined by XRF (Thermo Scientific, ARL 9900, Waltham, MA, USA). The approach uses $\mathrm{X}$-rays to excite the sample, which in turn causes the sample to emit secondary $\mathrm{X}$-rays These secondary (or fluorescent) X-rays are characteristic of the element from which they were emitted, and so can be indicative of the elemental composition of the sample. A Bruker X'Pert Pro powder diffraction instrument (Bruker, Karlsruhe, Germany) (with X'Celerator detector, $\mathrm{Cu} \mathrm{K} \alpha \mathrm{X}$-radiation, and $2 \theta$ scans from 10 to $90 \mathrm{deg}$ ) was used to analyse the crystalline phases in the samples. The phase compositions and microstructures were examined using field emission scanning electron microscopy (SEM) (Nova 400 Nano SEM; FEI, Hillsboro, OR, USA) at a setting of $20 \mathrm{kV}$ and coupled with EDS (INCA, IE 350 Penta FET X-3, Oxford Instruments, Oxford, UK). All the samples were coated with Au for SEM-EDS analysis.

\subsection{Determination of Particle Size of Ferronickel Particles}

Particle size analysis was performed using the software package ImageJ to metallic particles from 20 regions per sample, with each region observed using Scanning Electron Microscopy (SEM). The profile areas $S$ reported are calculated from the remaining population of particles on a per-sample basis. Because of the irregular shapes of ferronickel particles, the shape of particles was assumed to be spherical [40]. Therefore, the equivalent size $d$ of a single ferronickel particle was calculated using Equation (3):

$$
d=2 \sqrt{\frac{S}{\pi}}
$$

The equivalent sizes of ferronickel particles in the 20 continuous view fields were summarized and statistically analysed. All ferronickel particles were divided into several intervals at a step length of $2 \mu \mathrm{m}$ according to the equivalent size. The mathematical average equivalent size $\overline{d_{i}}$ of the ferronickel particles within each interval was calculated. Therefore, the average equivalent size $\bar{d}$ of ferronickel particles in 20 view fields was calculated using Equation (4):

$$
\bar{d}=\sum_{1}^{n} \overline{d_{i}} \frac{S_{i}}{S_{\mathrm{T}}} \times 100 \%
$$

where $S_{i}$ is the total profile area of ferronickel particles within a certain interval, and $S_{\mathrm{T}}$ is the total profile area of all ferronickel particles in the 20 view fields.

\section{Results and Discussion}

\subsection{Self-Reduction of Saprolitic Laterite Ore}

The thermodynamic analysis of the carbothermic reduction roasting of nickeliferous limonitic laterite ore has been performed by Pickles [41]. The major nickel-bearing phase in the limonitic ores is goethite, for a saprolitic laterite ore, the nickel is widely disseminated in solid solution in the host rock [10], nickel oxide-containing chlorite and goethite undergoes a dehydroxylation reaction and 
form nickel oxide and iron oxide. Thus, ideal behavior has been assumed in one or more of the phases, so the reactions for the self-reduction of nickel and oxides from nickel laterite ore would be as follows:

$$
\begin{gathered}
3 \mathrm{Fe}_{2} \mathrm{O}_{3}+\mathrm{C}=2 \mathrm{Fe}_{3} \mathrm{O}_{4}+\mathrm{CO}(\mathrm{g}) \\
\mathrm{Fe}_{2} \mathrm{O}_{3}+\mathrm{C}=2 \mathrm{FeO}+\mathrm{CO}(\mathrm{g}) \\
\mathrm{Fe}_{2} \mathrm{O}_{3}+3 \mathrm{C}=2 \mathrm{Fe}+3 \mathrm{CO}(\mathrm{g}) \\
\mathrm{Fe}_{3} \mathrm{O}_{4}+\mathrm{C}=3 \mathrm{FeO}+\mathrm{CO}(\mathrm{g}) \\
\mathrm{Fe}_{3} \mathrm{O}_{4}+4 \mathrm{C}=3 \mathrm{Fe}+4 \mathrm{CO}(\mathrm{g}) \\
\mathrm{FeO}+\mathrm{C}=\mathrm{Fe}+\mathrm{CO}(\mathrm{g}) \\
\mathrm{NiO}+\mathrm{C}=\mathrm{Ni}+\mathrm{CO}(\mathrm{g})
\end{gathered}
$$

Since the self-reduction reactions produce carbon monoxide, the gaseous reduction of nickel and iron oxides would be:

$$
\begin{gathered}
3 \mathrm{Fe}_{2} \mathrm{O}_{3}+\mathrm{CO}(\mathrm{g})=2 \mathrm{Fe}_{3} \mathrm{O}_{4}+\mathrm{CO}_{2}(\mathrm{~g}) \\
\mathrm{Fe}_{2} \mathrm{O}_{3}+\mathrm{CO}(\mathrm{g})=2 \mathrm{FeO}+\mathrm{CO}_{2}(\mathrm{~g}) \\
\mathrm{Fe}_{2} \mathrm{O}_{3}+3 \mathrm{CO}(\mathrm{g})=2 \mathrm{Fe}+3 \mathrm{CO}_{2}(\mathrm{~g}) \\
\mathrm{Fe}_{3} \mathrm{O}_{4}+\mathrm{CO}(\mathrm{g})=3 \mathrm{FeO}+\mathrm{CO}_{2}(\mathrm{~g}) \\
\mathrm{Fe}_{3} \mathrm{O}_{4}+4 \mathrm{CO}(\mathrm{g})=3 \mathrm{Fe}+4 \mathrm{CO}_{2}(\mathrm{~g}) \\
\mathrm{FeO}+\mathrm{CO}(\mathrm{g})=\mathrm{Fe}+\mathrm{CO}_{2}(\mathrm{~g}) \\
\mathrm{NiO}+\mathrm{CO}(\mathrm{g})=\mathrm{Ni}+\mathrm{CO}_{2}(\mathrm{~g})
\end{gathered}
$$

In the metal phase, a solid solution of ferronickel alloy would form.

\subsection{Effect of on the Particle Size and Distribution of Ferronickel Particles}

The anthracite dosage was fixed at $7.88 \mathrm{wt} \%$ which was calculated based on the $\mathrm{C} / \mathrm{O}$ ratio, nickel laterite ore without additive was reduced at $1200^{\circ} \mathrm{C}$ for $30 \mathrm{~min}$ to the sufficient reduction of nickel and iron oxides. The micrograph of the reduced nickel laterite ore is shown in Figure 2. As shown in Figure 2, the nickel and iron oxides were reduced to form fine ferronickel particles that dispersed and embedded in silicates.

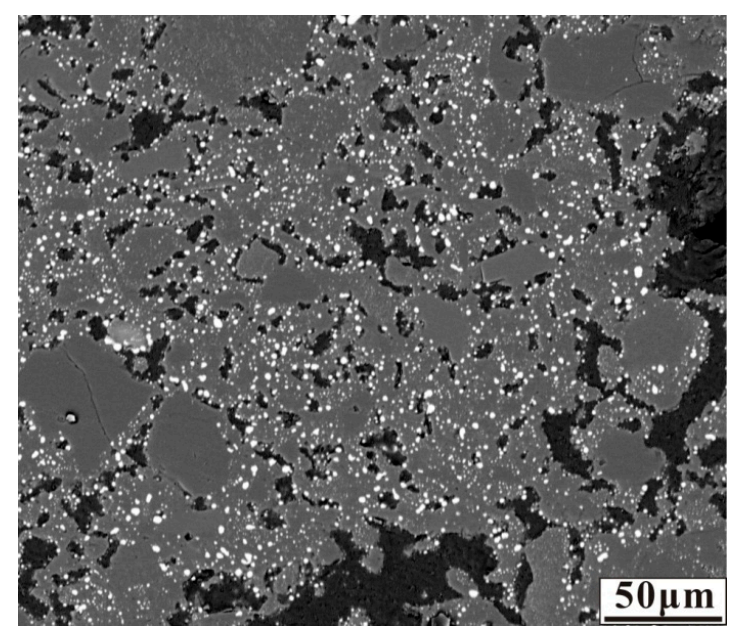

Figure 2. Micrograph of nickel laterite ore sample reduced at $1200{ }^{\circ} \mathrm{C}$ for $30 \mathrm{~min}$ with $7.88 \mathrm{wt} \%$ coal in the absence of additive. 
The effects of the various calcium, sulphur, and calcium oxide additions on the size and distribution of ferronickel particles are demonstrated in the micrographs in Figures 3-5. These micrographs depict representative areas from samples reduced at $1200{ }^{\circ} \mathrm{C}$ for $30 \mathrm{~min}$. As seen in Figure 3 , a trend of ferronickel particle size increased with increasing calcium sulphate addition is evident. The number of ferronickel particles decreased, and larger particles aggregated at the boundary between the hole and the gangue due to the aggregation and growth of fine ferronickel particles.

In the case of Figure 4, sulphur addition resulted in similar ferronickel particle size and distribution as in the absence of additive case. Sulphur significantly decreases the surface tension of metal particles, and thus the elastic resistance of metal particles agglomeration decreases [33]. As a saprolitic laterite ore with a great mass of gangue different from that of the limonitic laterite ore, the migration of ferronickel particles in gangue is an important factor for the aggregation and growth of fine ferronickel particles, and the low reduction temperature was not conducive to ferronickel particle migration.

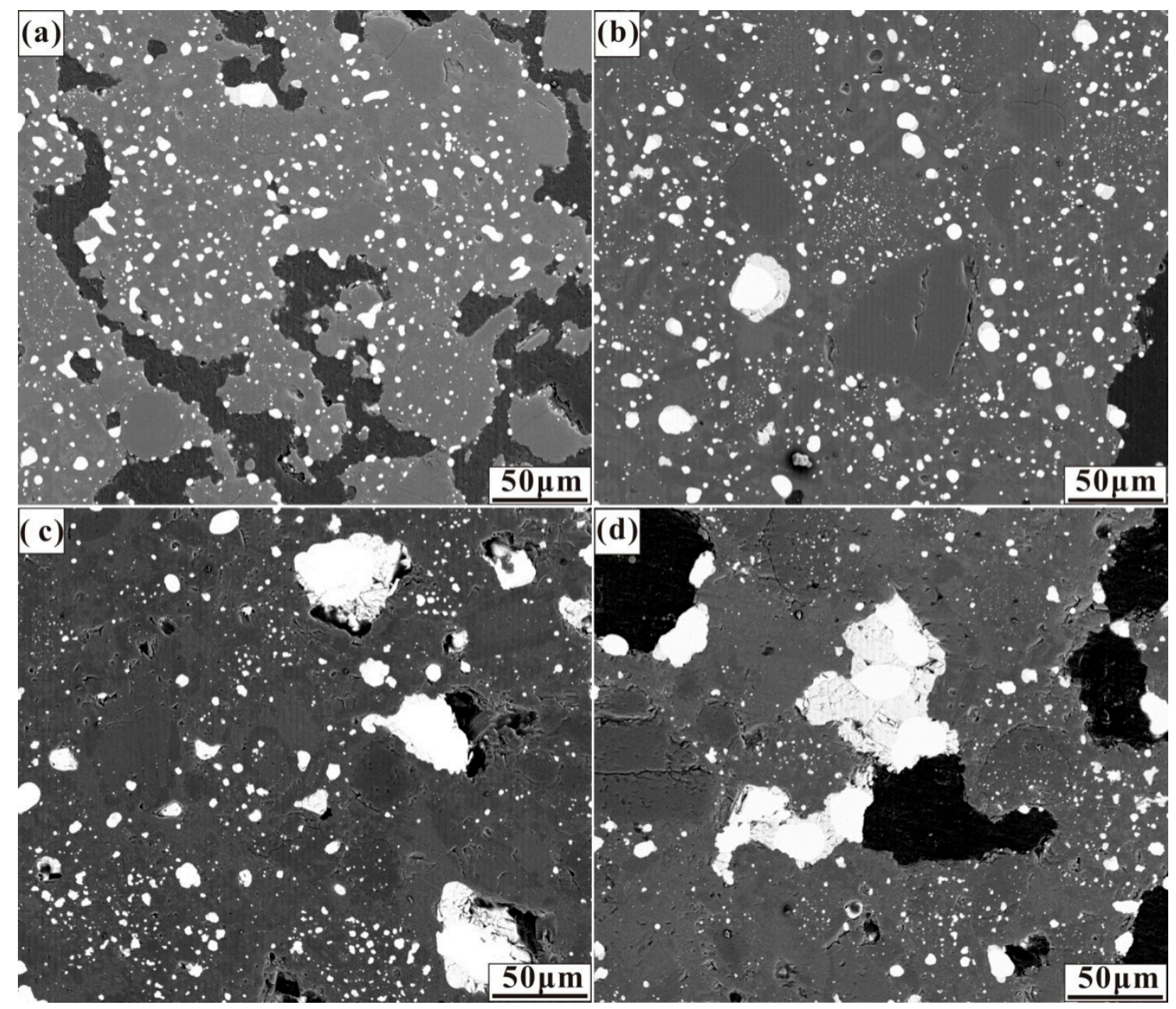

Figure 3. Micrographs of nickel laterite ore samples reduced at $1200{ }^{\circ} \mathrm{C}$ for $30 \mathrm{~min}$ with $7.88 \mathrm{wt} \%$ coal and (a) $4 \mathrm{wt} \% \mathrm{CaSO}_{4}$, (b) $8 \mathrm{wt} \% \mathrm{CaSO}_{4}$, (c) $12 \mathrm{wt} \% \mathrm{CaSO}_{4}$, and (d) $16 \mathrm{wt} \% \mathrm{CaSO}_{4}$.

As seen in the micrographs in Figure 5, there is an increase in particle size resulting from the increased addition of calcium oxide, with few calcium oxide additions demonstrating a slight influence on the size and distribution of ferronickel particles. Relatively large ferronickel particles were observed at the boundary between the hole and the gangue with the calcium oxide dosage up to $6.6 \mathrm{wt} \%$. Calcium oxide reacted with silica to form a low melting point mineral [19], which promoted ferronickel particle migration in the gangue. 
The profile area of ferronickel particles was obtained using ImageJ software, and the average particle size was calculated according to Equations (2) and (3). The results are shown in Figure 6. Ferronickel particles in the absence of additive considered here were on average of $0.975 \mu \mathrm{m}$, significantly smaller than the ferronickel particles formed in the presence of additives. The average size of ferronickel particles exceeded $20 \mu \mathrm{m}$ with increasing calcium sulphate dosage to $12 \mathrm{wt} \%$. With respect to sulphur and calcium oxide addition, increasing the addition led to the growth of ferronickel particles, but the average size was less than $5 \mu \mathrm{m}$. As the dosage of sulphur or calcium oxide addition was the sulphur or calcium oxide content of calcium sulphate, the increase in particle growth resulting from the increased addition of calcium sulphate is significantly greater than that observed for a similar increase in the mass of sulphur or calcium oxide. This suggests that the mechanism of calcium sulphate to aid the growth of the ferronickel particles was not the result of either sulphur or calcium oxide acting unilaterally.
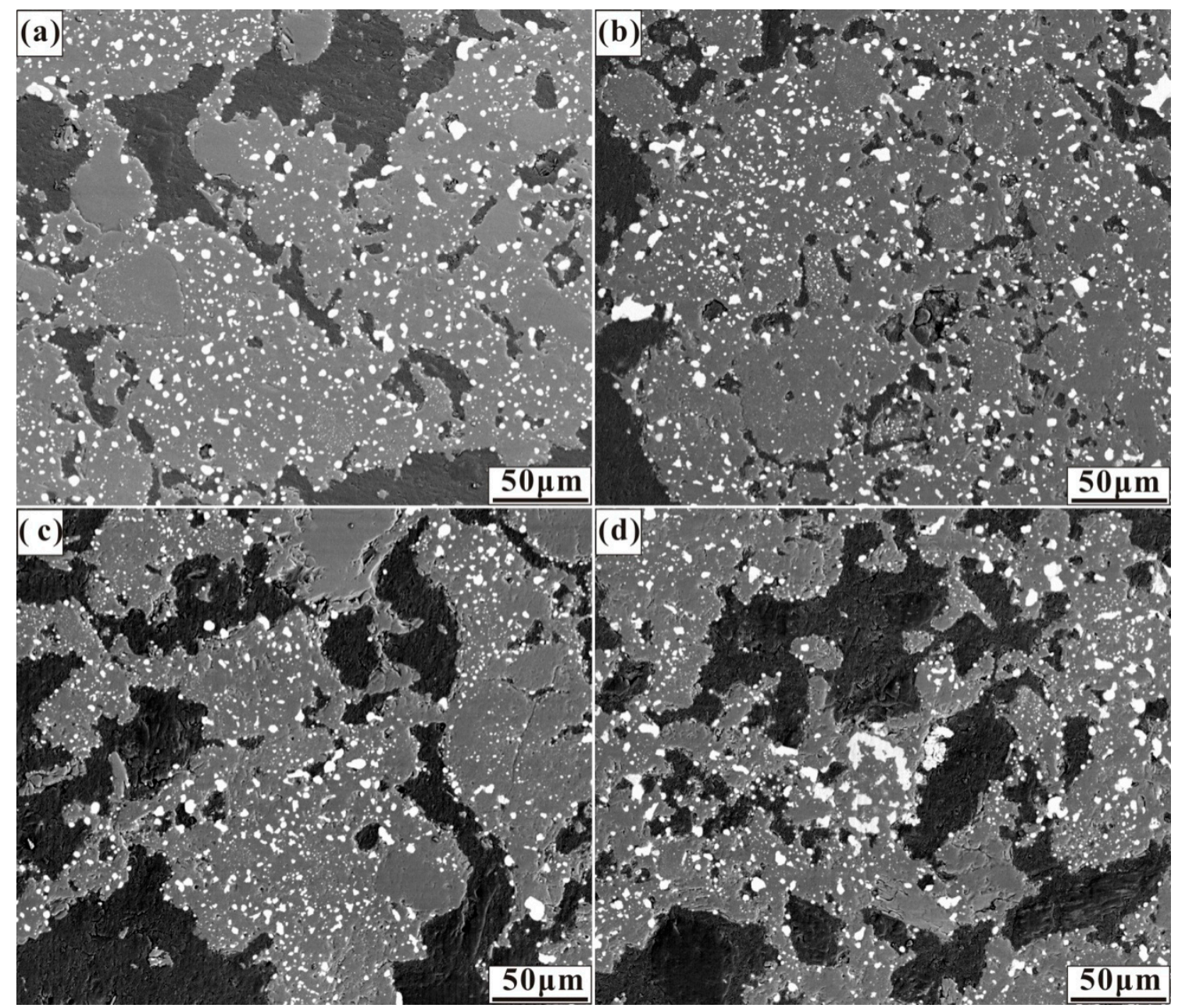

Figure 4. Micrographs of nickel laterite ore samples reduced at $1200{ }^{\circ} \mathrm{C}$ for $30 \mathrm{~min}$ with $7.88 \mathrm{wt} \%$ coal and (a) $0.94 \mathrm{wt} \%$ sulphur, (b) $1.88 \mathrm{wt} \%$ sulphur, (c) $2.82 \mathrm{wt} \%$ sulphur, and (d) $3.76 \mathrm{wt} \%$ sulphur. 


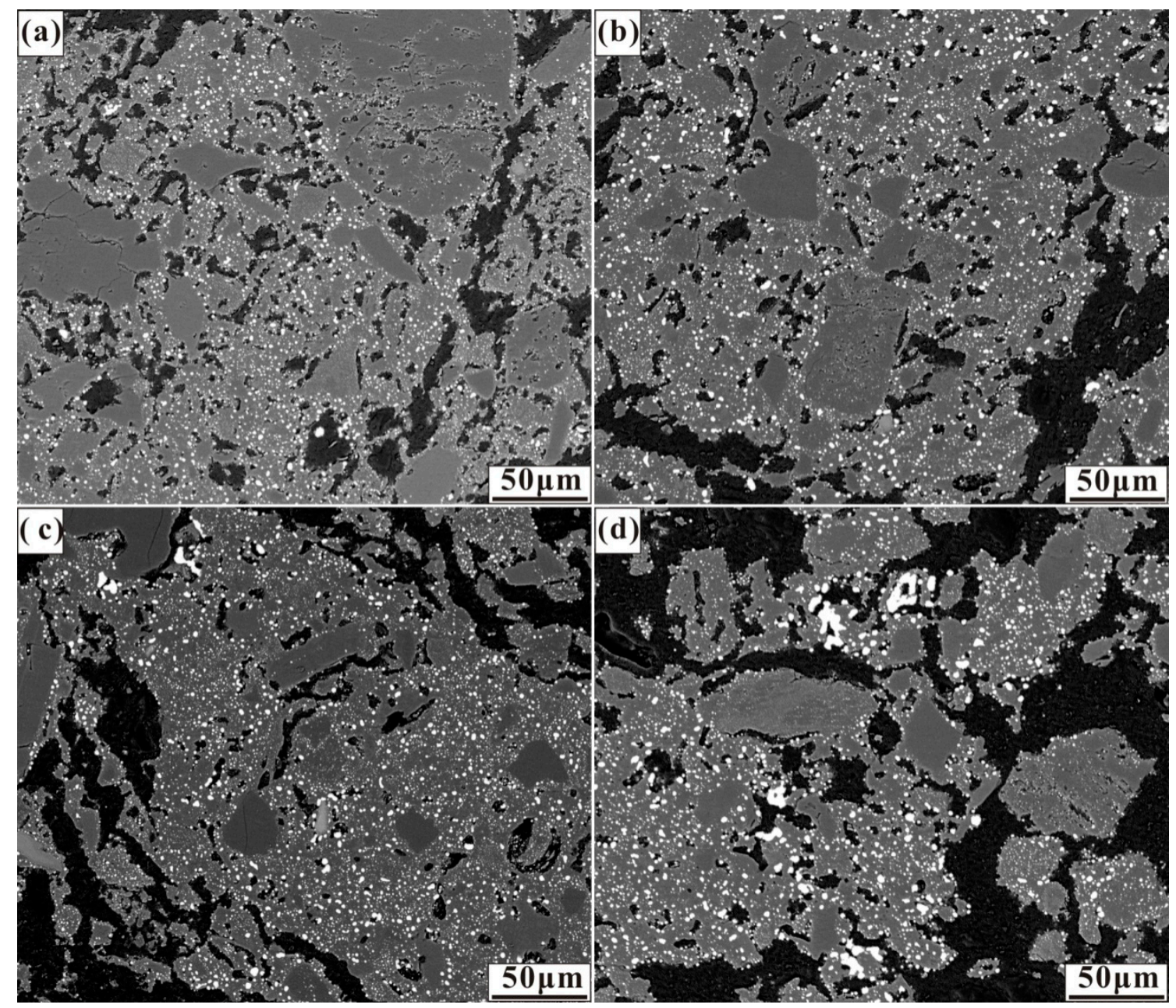

Figure 5. Micrographs of nickel laterite ore samples reduced at $1200{ }^{\circ} \mathrm{C}$ for $30 \mathrm{~min}$ with $7.88 \mathrm{wt} \%$ coal and (a) $1.65 \mathrm{wt} \% \mathrm{CaO}$, (b) $3.3 \mathrm{wt} \% \mathrm{CaO}$, (c) $4.95 \mathrm{wt} \% \mathrm{CaO}$, and (d) $6.6 \mathrm{wt} \% \mathrm{CaO}$.

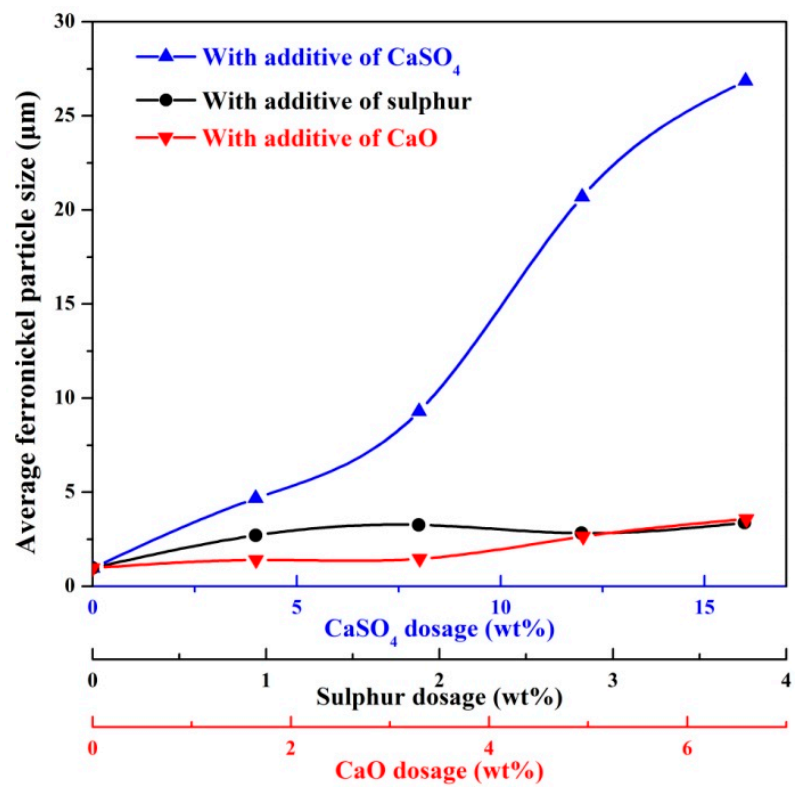

Figure 6. The average ferronickel particle size from samples with $7.88 \mathrm{wt} \%$ coal in the absence and presence of additive, reduced at a reduction temperature of $1200^{\circ} \mathrm{C}$ for $30 \mathrm{~min}$. 
The profile area of ferronickel particles was used to represent the distribution of ferronickel, and the distribution of ferronickel with different particle sizes is presented in Figure 7 . In the absence of additive, approximately $85 \%$ of ferronickel particles have a particle size less than $2 \mu \mathrm{m}$, and no particles above $6 \mu \mathrm{m}$ were observed. The presence of calcium sulphate in the ore results in a shift towards larger particles. More than $70 \%$ of ferronickel formed ferronickel particles larger than $10 \mu \mathrm{m}$ with calcium sulphate addition up to $16 \mathrm{wt} \%$. With the addition of merely sulphur or calcium oxide, most ferronickel particles were smaller than $4 \mu \mathrm{m}$.

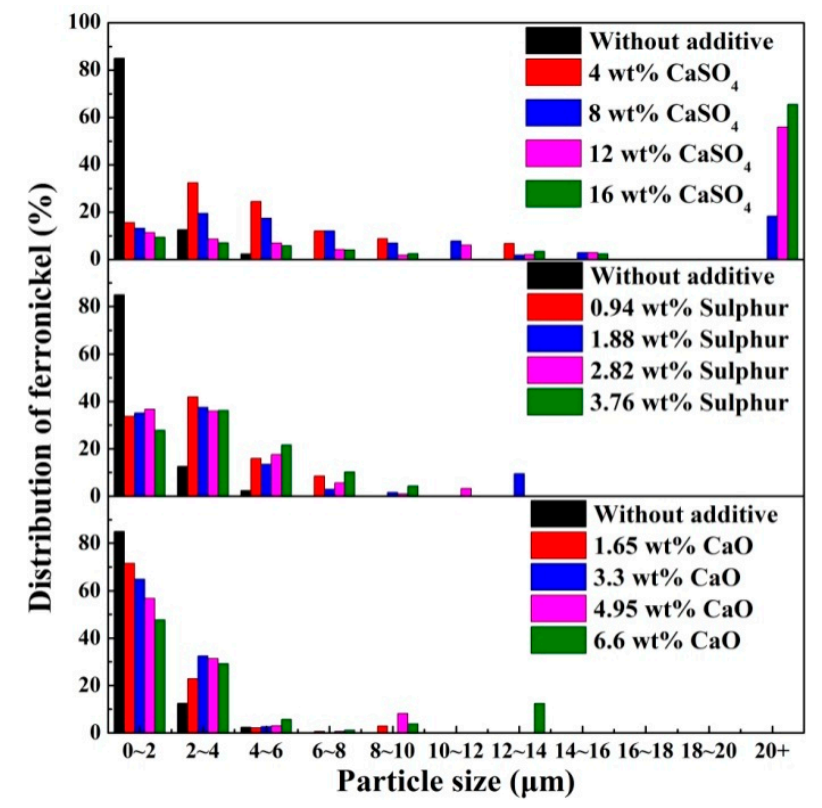

Figure 7. Distribution of ferronickel from samples with $7.88 \mathrm{wt} \%$ coal in the absence and presence of additive, reduced at a reduction temperature of $1200{ }^{\circ} \mathrm{C}$ for $30 \mathrm{~min}$.

\subsection{Mechanism of Calcium Sulphate on the Aggregation and Growth of Ferronickel Particles}

X-ray diffraction analysis (XRD) was carried out to demonstrate the differences in mineral composition with the addition of different additives are shown in Figure 8 . Combining the XRD pattern of the original ore (Figure 1) and samples reduced at $1200{ }^{\circ} \mathrm{C}$ for comparison, all the goethite phase disappeared and phase transformation occurs to $\mathrm{Fe}_{2} \mathrm{O}_{3}$ and ferronickel alloy [13]. Clinoenstatite $\left(\mathrm{MgSiO}_{3}\right)$ and forsterite $\left((\mathrm{Mg}, \mathrm{Fe})_{2} \mathrm{SiO}_{4}\right)$ are resulted from the dehydroxylation of Fe-substituted lizardite $\left[(\mathrm{Mg}, \mathrm{Fe})_{3} \mathrm{Si}_{2} \mathrm{O}_{5}(\mathrm{OH})_{4}\right]$ and the recrystallization of silicate minerals [21-23]. The new mineralogical compositions of pigeonite $\left(\mathrm{Ca}(\mathrm{Mg}, \mathrm{Fe}) \mathrm{Si}_{2} \mathrm{O}_{6}\right)$ and troilite $(\mathrm{FeS})$ in the reduced nickel laterite ore with a dosage of $16 \mathrm{wt} \%$ calcium sulphate appeared. Calcium sulphate decomposed to calcium oxide and sulphur in a reducing atmosphere [35].

$$
2 \mathrm{CaSO}_{4}+6 \mathrm{CO}=2 \mathrm{CaO}+\mathrm{S}_{2}+6 \mathrm{CO}_{2}
$$

Calcium oxide reacted with silicate to form pigeonite, troilite generated by the reaction of $\mathrm{S}_{2}$ with iron oxides or iron $[25,34]$. As a similar mechanism, pigeonite was found in the reduced sample in the presence of calcium oxide and troilite appeared in the reduced sample with an additive of sulphur.

The microstructures and elemental maps of samples with calcium sulphate, sulphur and calcium oxide addition reduced at $1200{ }^{\circ} \mathrm{C}$ were analysed by SEM coupled with EDS are shown in Figures 9-11. The corresponding EDS results of the mineral composition are listed in Tables 2-4. 


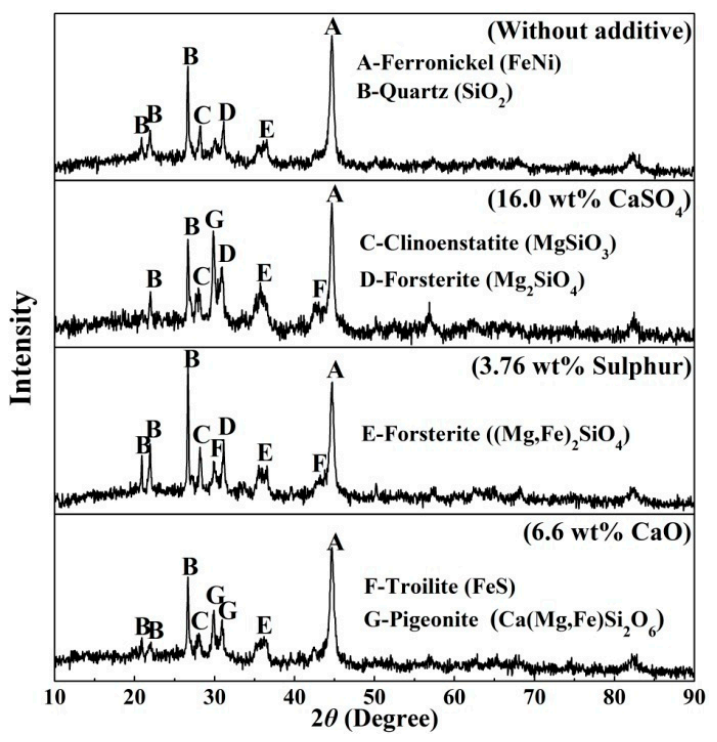

Figure 8. Mineralogical compositions of samples with different additives reduced at $1200^{\circ} \mathrm{C}$ for $30 \mathrm{~min}$.
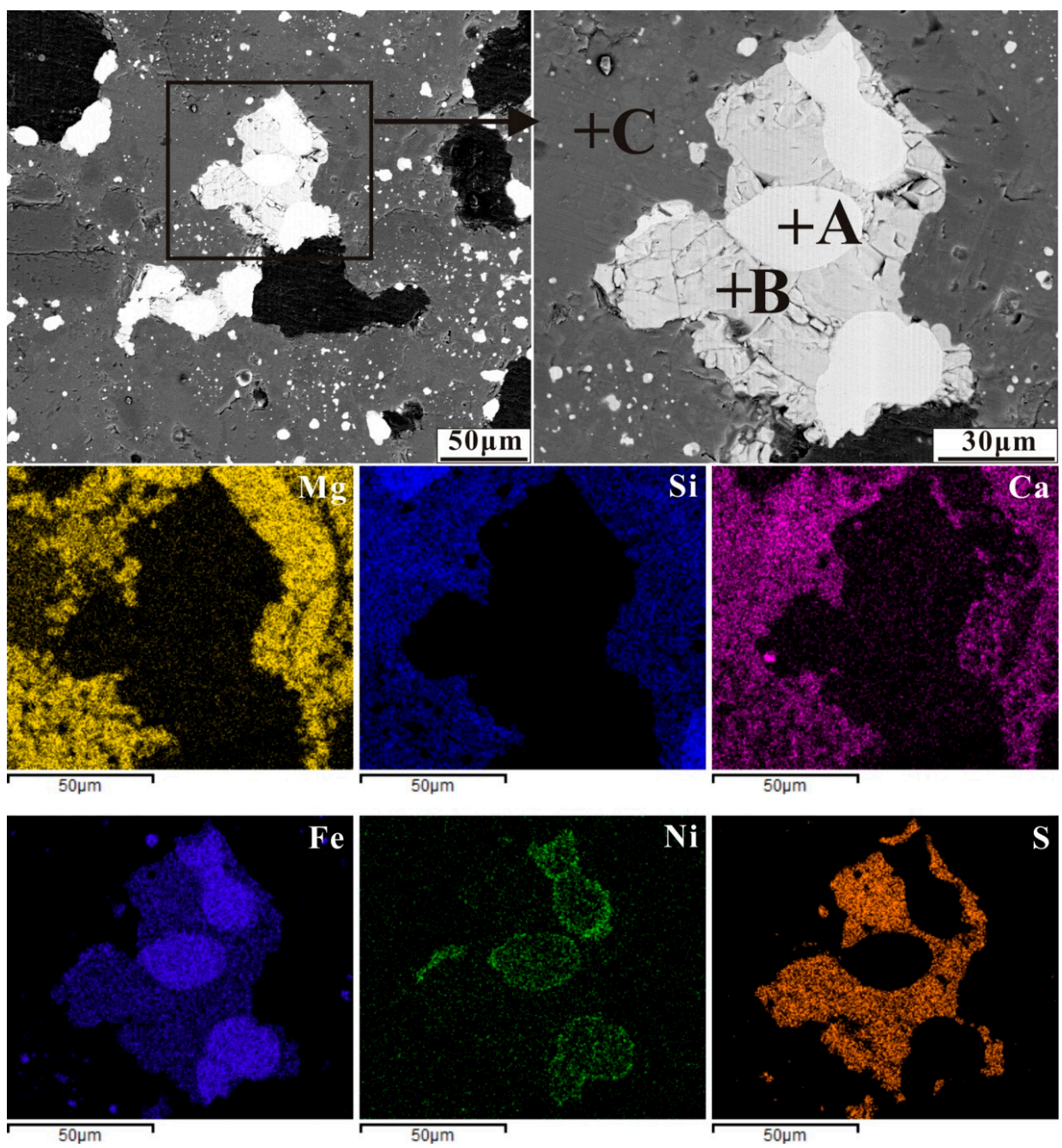

Figure 9. Back-scattered electron (BSE) image of nickel laterite ore with an additive of $16 \mathrm{wt} \% \mathrm{CaSO}_{4}$ by reducing at $1200^{\circ} \mathrm{C}$ for $30 \mathrm{~min}$ (A-ferronickel, B-troilite and C-silicate), and elemental maps for $\mathrm{Mg}$, $\mathrm{Si}, \mathrm{Ca}, \mathrm{Fe}, \mathrm{Ni}$ and $\mathrm{S}$. 

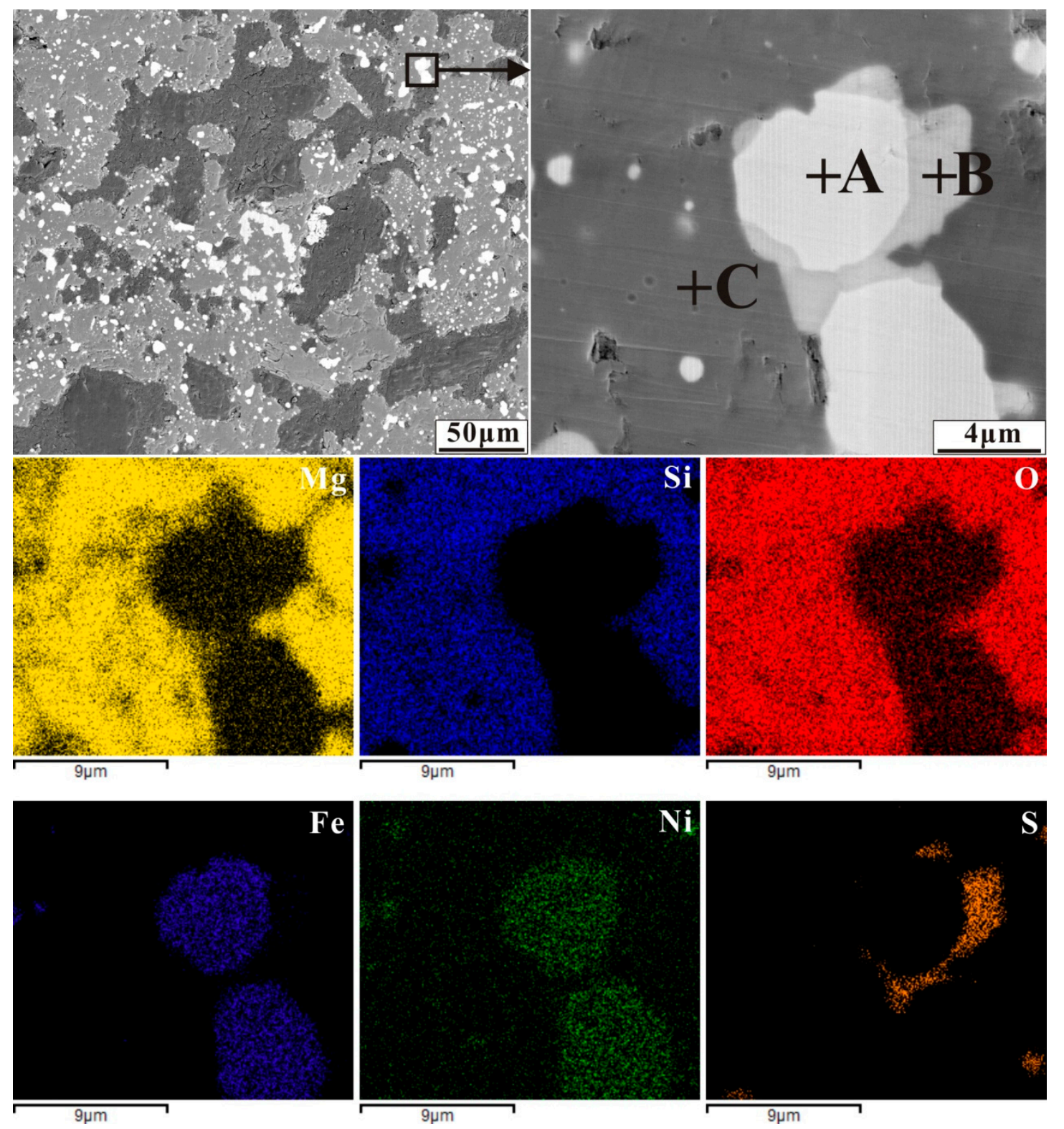

Figure 10. Back-scattered electron (BSE) image of nickel laterite ore with an additive of $3.72 \mathrm{wt} \%$ sulphur by reducing at $1200{ }^{\circ} \mathrm{C}$ for $30 \mathrm{~min}$ (A-ferronickel, B-troilite and C-silicate), and elemental maps for $\mathrm{Mg}, \mathrm{Si}, \mathrm{O}, \mathrm{Fe}, \mathrm{Ni}$ and $\mathrm{S}$.

Table 2. EDS analysis of mineral composition in the reduced sample with $\mathrm{CaSO}_{4}$ addition in Figure 9 (at $\%)$.

\begin{tabular}{ccccccccc}
\hline Mineral & Fe & Ni & Cr & S & O & Si & Mg & Ca \\
\hline A-ferronickel & 91.76 & 8.24 & - & - & - & - & - & - \\
B-troilite & 40.96 & - & 8.15 & 50.89 & - & - & - & - \\
C-silicate & - & - & - & - & 54.27 & 26.96 & 11.21 & 7.56 \\
\hline
\end{tabular}




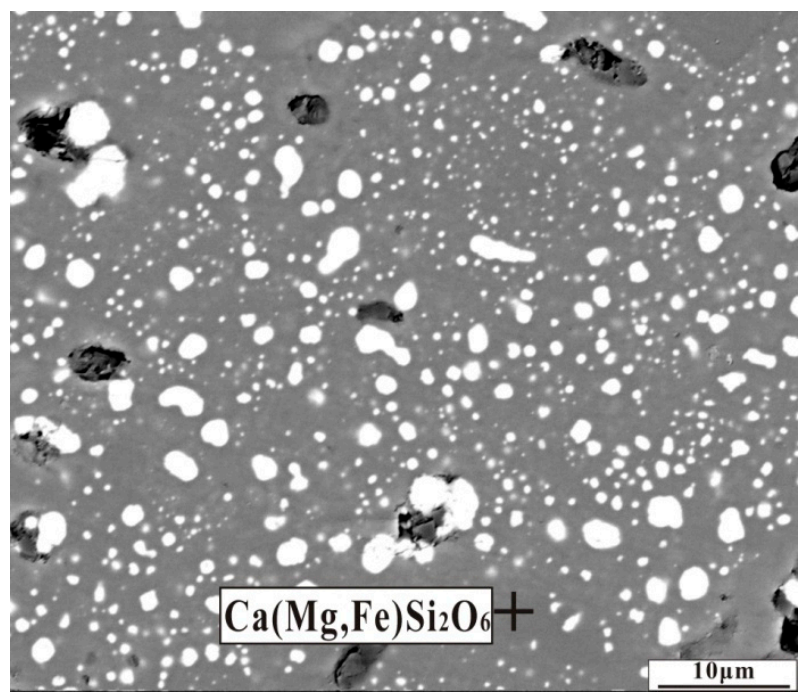

Figure 11. Back-scattered electron (BSE) image of nickel laterite ore with an additive of $6.6 \mathrm{wt} \% \mathrm{CaO}$ by reducing at $1200{ }^{\circ} \mathrm{C}$ for $30 \mathrm{~min}$.

Table 3. EDS analysis of mineral composition in the reduced sample with sulphur addition in Figure 10 (at $\%)$.

\begin{tabular}{ccccccccc}
\hline Mineral & Fe & Ni & Cr & S & O & Si & Mg & Ca \\
\hline A-ferronickel & 91.26 & 8.74 & - & - & - & - & - & - \\
B-troilite & 35.59 & - & 14.17 & 50.24 & - & - & & - \\
C-silicate & - & - & - & - & 52.41 & 29.32 & 16.7 & 1.57 \\
\hline
\end{tabular}

Table 4. EDS analysis of mineral composition in the reduced sample with CaO addition in Figure 11 (at\%).

\begin{tabular}{cccccc}
\hline Mineral & Fe & O & Si & Mg & Ca \\
\hline C-silicate & 2.57 & 48.92 & 32.47 & 11.76 & 4.29 \\
\hline
\end{tabular}

In the case of Figure 9, troilite was present as a greyish white phase, surrounded the ferronickel particles or bridges with different big ferronickel particles, and reacted with iron to form an $\mathrm{Fe}-\mathrm{FeS}$ eutectic [35]. The Fe-FeS eutectic as a low-melting-point mineral wrapped ferronickel particles and migrated in gangue together, different ferronickel particles aggregated and grew up by bridge in the migration process, then precipitated at the boundary between the hole and the gangue. Chromium and nickel oxides were also sulphurized by $\mathrm{S}_{2}, \mathrm{NiS}$ then reacted with $\mathrm{FeO}$ to form $\mathrm{FeS}$ in a $\mathrm{CO}$ atmosphere [26].

$$
\begin{gathered}
2 \mathrm{Cr}_{2} \mathrm{O}_{3}+3 \mathrm{C}+3 \mathrm{~S}_{2}=2 \mathrm{Cr}_{2} \mathrm{~S}_{3}+3 \mathrm{CO}_{2} \\
2 \mathrm{NiO}+\mathrm{C}+\mathrm{S}_{2}=2 \mathrm{NiS}+\mathrm{CO}_{2} \\
\mathrm{NiS}+\mathrm{FeO}+\mathrm{CO}=\mathrm{Ni}+\mathrm{FeS}+\mathrm{CO}_{2}
\end{gathered}
$$

Meanwhile, calcium oxide from the decomposition of calcium sulphate in the reduction atmosphere, reacted readily with silicate to form a low-melting-point mineral accelerated the migration of ferronickel particles in gangue and facilitated their aggregation and growth. The mechanism of calcium sulfate in promoting the ferronickel particle growth is similar to that of sodium sulfate described by Jiang [21].

The case of sulphur is shown in Figure 10. It also appears that a sulphide network surrounds the ferronickel particles. However, ferronickel particles encased in the Fe-FeS eutectic are still embedded in silicate. Forsterite is an island structure silicate with a compact crystalline structure, limiting the migration of ferronickel particles. 
An appropriate amount of calcium oxide contributes to liquid generation and slag viscosity [15]. In the present work, the dosage of calcium oxide addition was $6.6 \mathrm{wt} \%$ less than that of the literature [15], and the reduction temperature of $1200{ }^{\circ} \mathrm{C}$ was also low. These conditions could not favor the liquid generation. Furthermore, calcium oxide transformed the compact structure of forsterite and the formation of a loose mineral structure was conducive to the migration of ferronickel particles in the gangue.

\subsection{Effect of Additive on Reduction and Magnetic Separation}

\subsubsection{Analysis of Magnetic Products}

Magnetic products were obtained from reduced nickel laterite ore by fine grinding and magnetic separation, the compositions of magnetic products are shown in Table 5. Magnetic separation results of nickel laterite ore reduced without additive are undesirable as the $\mathrm{Ni}$ and $\mathrm{Fe}$ grades are only $5.59 \mathrm{wt} \%$ and $60.23 \mathrm{wt} \%$, and the gangue compositions of $\mathrm{SiO}_{2}$ and $\mathrm{MgO}$ are $13.35 \mathrm{wt} \%$ and $4.88 \mathrm{wt} \%$, respectively. Generally, when the metallic particles have a particle size of less than $10 \mu \mathrm{m}$, they are very difficult to liberate during the grinding process, and very difficult to recover even if liberated [42-44]. The nickel and iron grades continuously improved with the increase of calcium sulphate dosage. By comparison with those in the absence of calcium sulphate, the nickel content of ferronickel concentrate increases significantly from $5.59 \mathrm{wt} \%$ to $8.52 \mathrm{wt} \%$ in the presence of $16 \mathrm{wt} \%$ calcium sulphate. As the ferronickel particles obtained in the presence of sulphur or calcium oxide smaller than $10 \mu \mathrm{m}$, in this case, there is a less-than-ideal separation between the ferronickel particles and the gangue achieved.

Table 5. Compositions of magnetic products.

\begin{tabular}{ccccccc}
\hline Components (wt\%) & $\mathbf{S i O}_{\mathbf{2}}$ & $\mathbf{M g O}$ & $\mathbf{C a O}$ & $\mathbf{T F e}$ & $\mathbf{N i}$ & $\mathbf{S}$ \\
\hline Without additive & 13.35 & 4.88 & - & 60.23 & 5.59 & - \\
$4 \mathrm{wt} \% \mathrm{CaSO}_{4}$ & 9.27 & 3.38 & 0.66 & 62.25 & 6.37 & 0.21 \\
$8 \mathrm{wt} \% \mathrm{CaSO}_{4}$ & 6.1 & 2.3 & 0.58 & 71.02 & 7.24 & 0.26 \\
$12 \mathrm{wt} \% \mathrm{CaSO}_{4}$ & 4.86 & 1.81 & 0.62 & 79.98 & 8.08 & 0.38 \\
$16 \mathrm{wt} \% \mathrm{CaSO}_{4}$ & 4.03 & 1.64 & 0.68 & 80.75 & 8.52 & 0.42 \\
$0.94 \mathrm{wt} \% \mathrm{Sulphur}$ & 13.25 & 4.79 & - & 60.21 & 5.66 & 0.15 \\
$1.88 \mathrm{wt} \% \mathrm{Sulphur}$ & 13.18 & 4.72 & - & 60.3 & 5.78 & 0.17 \\
$2.82 \mathrm{wt} \% \mathrm{Sulphur}$ & 13.12 & 4.69 & - & 59.83 & 6.27 & 0.23 \\
$3.76 \mathrm{wt} \% \mathrm{Sulphur}$ & 13.1 & 4.7 & - & 59.62 & 6.54 & 0.27 \\
$1.65 \mathrm{wt} \% \mathrm{CaO}$ & 13.16 & 4.69 & 0.76 & 60.57 & 5.71 & - \\
$3.3 \mathrm{wt} \% \mathrm{CaO}$ & 13.04 & 4.22 & 1.02 & 60.83 & 5.76 & - \\
$4.95 \mathrm{wt} \% \mathrm{CaO}$ & 12.52 & 4.08 & 1.41 & 61.53 & 5.88 & - \\
$6.6 \mathrm{wt} \% \mathrm{CaO}$ & 12.17 & 3.35 & 1.97 & 61.65 & 5.94 & - \\
\hline
\end{tabular}

\subsubsection{Analysis of Slags}

The compositions of slags were calculated by mass balance calculation and the results are shown in Table 6. With increasing calcium sulphate dosage, the nickel and iron contents of slag decrease. In the presence of sulphur or calcium oxide, the compositions of slags are consistent with that in the absence of additive. The results show that calcium sulphate is beneficial to separate ferronickel from the slag. 
Table 6. Compositions of slags.

\begin{tabular}{ccccccc}
\hline Components (wt\%) & $\mathbf{S i O}_{\mathbf{2}}$ & $\mathbf{M g O}$ & $\mathbf{C a O}$ & $\mathbf{T F e}$ & $\mathbf{N i}$ & $\mathbf{S}$ \\
\hline Without additive & 46.6 & 16.4 & - & 7.9 & 0.6 & - \\
$4 \mathrm{wt} \% \mathrm{CaSO}_{4}$ & 47.89 & 16.8 & 2.86 & 7.1 & 0.42 & 1.08 \\
$8 \mathrm{wt} \% \mathrm{CaSO}_{4}$ & 47.6 & 16.7 & 4.79 & 6.14 & 0.33 & 2.18 \\
$12 \mathrm{wt} \% \mathrm{CaSO}_{4}$ & 48.65 & 17.07 & 6.8 & 3.79 & 0.1 & 3.29 \\
$16 \mathrm{wt} \% \mathrm{CaSO} 4$ & 48.9 & 17.14 & 8.78 & 3.45 & 0.04 & 4.4 \\
$0.94 \mathrm{wt} \%$ Sulphur & 46.75 & 16.4 & - & 8.04 & 0.61 & 1.09 \\
$1.88 \mathrm{wt} \%$ Sulphur & 46.82 & 16.43 & - & 7.94 & 0.58 & 2.2 \\
$2.82 \mathrm{wt} \% \mathrm{Sulphur}$ & 46.91 & 16.46 & - & 7.91 & 0.48 & 3.31 \\
$3.76 \mathrm{wt} \% \mathrm{Sulphur}$ & 46.97 & 16.48 & - & 7.86 & 0.42 & 4.43 \\
$1.65 \mathrm{wt} \% \mathrm{CaO}$ & 46.77 & 16.42 & 2.82 & 7.98 & 0.6 & - \\
$3.3 \mathrm{wt} \% \mathrm{CaO}$ & 47.04 & 16.59 & 4.76 & 7.55 & 0.56 & - \\
$4.95 \mathrm{wt} \% \mathrm{CaO}$ & 47.3 & 16.68 & 6.67 & 7.15 & 0.51 & - \\
$6.6 \mathrm{wt} \% \mathrm{CaO}$ & 47.69 & 16.95 & 8.6 & 6.65 & 0.45 & - \\
\hline
\end{tabular}

\subsubsection{Recoveries of $\mathrm{Ni}$ and $\mathrm{Fe}$}

Figure 12 presents the nickel and iron recoveries of the ferronickel concentrate obtained in the presence of different additives. The nickel recovery increase with increasing the dosage of additive, the increment of nickel recovery with calcium sulphate is significantly greater than that in the presence of sulphur or calcium oxide. The same phenomenon appears for the recovery of iron. These results suggest that large ferronickel particle favour the efficient recycling of nickel. In the presence of $12 \mathrm{wt} \%$ calcium sulphate, the corresponding nickel and iron recoveries are $92.59 \%$ and $79.9 \%$ respectively.
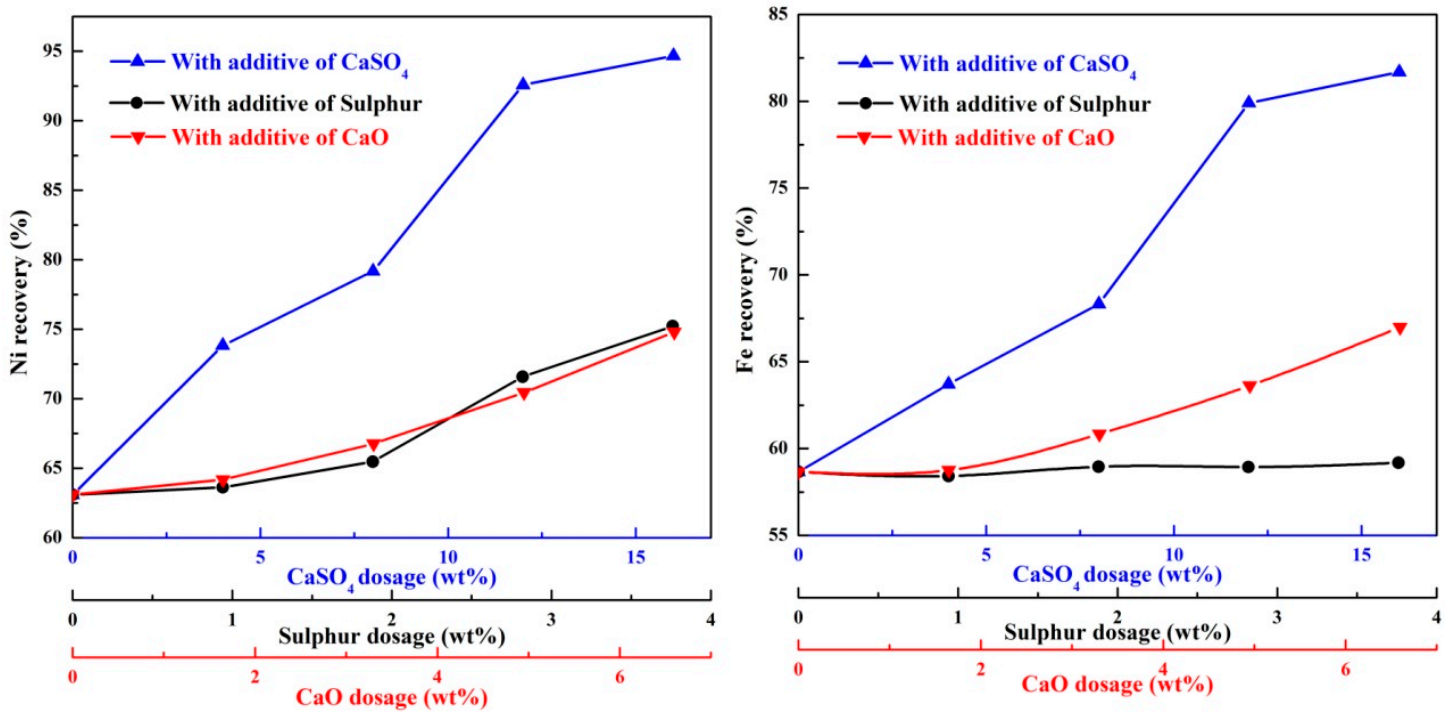

Figure 12. The nickel and iron recoveries of ferronickel concentrate with different additives.

\section{Conclusions}

Nickel laterite ore with an anthracite dosage of $7.88 \mathrm{wt} \%$ and a calcium sulphate addition of $16 \mathrm{wt} \%$ reduced at $1200{ }^{\circ} \mathrm{C}$ for $30 \mathrm{~min}$, a ferronickel concentrate with $8.52 \mathrm{wt} \% \mathrm{Ni}$, and $80.75 \mathrm{wt} \% \mathrm{Fe}$ was obtained by magnetic separation. The corresponding recoveries of $\mathrm{Ni}$ and Fe were $94.8 \%$ and $82.1 \%$, respectively.

The growth of ferronickel particles during the reduction roasting of a saprolitic laterite ore has been studied as a function of calcium sulphate, sulphur, and calcium oxide additions to the ore. The particle growth resulting from calcium sulphate is significantly greater than that resulting from sulphur or calcium oxide. Calcium sulphate decomposes to sulphur and calcium oxide in the reducing atmosphere. The low-melting-point Fe-FeS eutectic formed by the reaction of sulphur with iron oxides 
or iron which facilitate the migration of ferronickel particles. Calcium oxide could not contribute to liquid generation at a low temperature, but transforms the compact structure of forsterite, which is conducive to the migration of ferronickel particles in the gangue. Thus, large ferronickel particles precipitate at the boundary between the hole and the gangue. The results demonstrate that fine ferronickel particles in the reduced saprolitic laterite ore aggregate and grow up under the joint action of a liquid-phase growth mechanism driven by the Fe-FeS eutectic and a loose mineral structure formation by calcium oxide.

Author Contributions: G.H.: Data curation, Writing-original draft, Investigation. Z.X.: Conceptualization, Methodology. J.W.: Formal analysis. Y.W.: Writing-review \& editing. All authors have read and agreed to the published version of the manuscript.

Funding: This research did not receive any specific grant from funding agencies in the public, commercial, or not-for-profit sectors.

Conflicts of Interest: The authors declare no conflict of interest.

\section{References}

1. Dander, J.E.; Garg, N.K. Breaking amides using nickel catalysis. ACS Catal. 2017, 7, 1413-1423. [CrossRef] [PubMed]

2. Eckelman, M.J. Facility-level energy and greenhouse gas life-cycle assessment of the global nickel industry. Resour. Conserv. Recycl. 2010, 54, 256-266. [CrossRef]

3. Kim, J.; Dodbiba, G.; Tanno, H.; Okaya, K.; Matsuo, S.; Fujita, T. Calcination of low-grade laterite for concentration of ni by magnetic separation. Miner. Eng. 2010, 23, 282-288. [CrossRef]

4. Morcali, M.H.; Khajavi, L.T.; Dreisinger, D.B. Extraction of nickel and cobalt from nickeliferous limonitic laterite ore using borax containing slags. Int. J. Miner. Process. 2017, 167, 27-34. [CrossRef]

5. Sattar, R.; Ilyas, S.; Bhati, H.N.; Ghaffar, A. Resource recovery of critically-rare metals by hydrometallurgical recycling of spent lithium ion batteries. Sep. Purif. Technol. 2019, 209, 725-733. [CrossRef]

6. Yang, J.; Zhang, G.Q.; Ostrovski, O.; Jahanshahi, S. Selective reduction of an australian garnieritic laterite ore. Miner. Eng. 2019, 131, 79-89. [CrossRef]

7. Harris, C.T.; Peacey, J.G.; Pickles, C.A. Selective sulphidation of a nickeliferous lateritic ore. Miner. Eng. 2011, 24, 651-660. [CrossRef]

8. Farrokhpay, S.; Filippov, L.; Fornasiero, D. Pre-concentration of nickel in laterite ores using physical separation methods. Miner. Eng. 2019, 141, 105892. [CrossRef]

9. Forster, J.; Pickles, C.A.; Elliott, R. Microwave carbothermic reduction roasting of a low grade nickeliferous silicate laterite ore. Miner. Eng. 2016, 88, 18-27. [CrossRef]

10. Pickles, C.A.; Anthony, W. Thermodynamic modelling of the reduction of a saprolitic laterite ore by methane. Miner. Eng. 2018, 120, 47-59. [CrossRef]

11. Farrokhpay, S.; Fornasiero, D.; Filippov, L. Upgrading nickel in laterite ores by flotation. Miner. Eng. 2018, 121, 100-106. [CrossRef]

12. Xu, D.F.; Liu, L.X.; Quast, K.; Addai-Mensah, J.; Robinson, D.J. Effect of nickel laterite agglomerate properties on their leaching performance. Adv. Powder Technol. 2013, 24, 750-756. [CrossRef]

13. Ilyas, S.; Srivastava, R.R.; Kim, H.; Ilyas, N.; Sattar, R. Extraction of nickel and cobalt from a laterite ore using the carbothermic reduction roasting-ammoniacal leaching process. Sep. Purif. Technol. 2020, 232, 115971. [CrossRef]

14. Georgiou, D.; Papangelakis, V.G. Sulphuric acid pressure leaching of a limonitic laterite: Chemistry and kinetics. Hydrometallurgy 1998, 49, 23-46. [CrossRef]

15. Wang, Z.H.; Chu, M.S.; Liu, Z.G.; Wang, H.T.; Zhao, W.; Gao, L.H. Preparing ferro-nickel alloy from low-grade laterite nickel ore based on metallized reduction-magnetic separation. Metals 2017, 7, 313. [CrossRef]

16. Rao, M.J.; Li, G.H.; Jiang, T.; Luo, J.; Zhang, Y.B.; Fan, X.H. Carbothermic reduction of nickeliferous laterite ores for nickel pig iron production in china: A review. JOM 2013, 65, 1573-1583. [CrossRef]

17. Zheng, G.L.; Zhu, D.Q.; Pan, J.; Li, Q.H.; An, Y.M.; Zhu, J.H.; Liu, Z.H. Pilot scale test of producing nickel concentrate from low-grade saprolitic laterite by direct reduction-magnetic separation. J. Cent. South Univ. 2014, 21, 1771-1777. (In Chinese) [CrossRef] 
18. Zhu, D.Q.; Cui, Y.; Vining, K.; Hapugoda, S.; Douglas, J.; Pan, J.; Zheng, G.L. Upgrading low nickel content laterite ores using selective reduction followed by magnetic separation. Int. J. Miner. Process. 2012, 106, 1-7. [CrossRef]

19. Dong, J.C.; Wei, Y.G.; Zhou, S.W.; Li, B.; Yang, Y.D.; Mclean, A. The effect of additives on extraction of Ni, Fe and Co from nickel laterite ores. JOM 2018, 70, 2365-2377. [CrossRef]

20. Elliott, R.; Pickles, C.A.; Peacey, J. Ferronickel particle formation during the carbothermic reduction of a limonitic laterite ore. Miner. Eng. 2017, 100, 166-176. [CrossRef]

21. Jiang, M.; Sun, T.C.; Liu, Z.G.; Kou, J.; Na, L.; Zhang, S.Y. Mechanism of sodium sulfate in promoting selective reduction of nickel laterite ore during reduction roasting process. Int. J. Miner. Process. 2013, 123, 32-38. [CrossRef]

22. Li, B.; Wang, H.; Wei, Y.G. The reduction of nickel from low-grade nickel laterite ore using a solid-state deoxidisation method. Miner. Eng. 2011, 24, 1556-1562. [CrossRef]

23. Li, G.H.; Shi, T.M.; Rao, M.J.; Jiang, T.; Zhang, Y.B. Beneficiation of nickeliferous laterite by reduction roasting in the presence of sodium sulfate. Miner. Eng. 2012, 32, 19-26. [CrossRef]

24. Liu, Z.G.; Sun, T.C.; Wang, X.P.; Gao, E.X. Generation process of fes and its inhibition mechanism on iron mineral reduction in selective direct reduction of laterite nickel ore. Int. J. Miner. Metall. Mater. 2015, 22, 901-906. [CrossRef]

25. Lu, J.; Liu, S.J.; Shangguan, J.; Du, W.G.; Pan, F.; Yang, S. The effect of sodium sulphate on the hydrogen reduction process of nickel laterite ore. Miner. Eng. 2013, 49, 154-164. [CrossRef]

26. Rao, M.J.; Li, G.H.; Zhang, X.; Luo, J.; Peng, Z.W.; Jiang, T. Reductive roasting of nickel laterite ore with sodium sulfate for Fe-Ni production. Part i: Reduction/sulphidation characteristics. Sep. Sci. Technol. 2016, 51, 1727-1735. [CrossRef]

27. Wang, X.P.; Sun, T.C.; Chen, C.; Kou, J. Effects of $\mathrm{Na}_{2} \mathrm{SO}_{4}$ on iron and nickel reduction in a high-iron and low-nickel laterite ore. Int. J. Miner. Metall. Mater. 2018, 25, 383-390. [CrossRef]

28. Zhou, S.W.; Wei, Y.G.; Li, B.; Wang, H.; Ma, B.Z.; Wang, C.Y. Mechanism of sodium chloride in promoting reduction of high-magnesium low-nickel oxide ore. Sci. Rep. 2016, 6, 81-88. [CrossRef]

29. Liu, Z.G.; Sun, T.C.; Jiang, M.; Gao, E.X. Mechanism of $\mathrm{CaO}$ in direct reduction roasting of nickel laterite ore. J. Cent. South Univ. 2015, 46, 3566-3572. (In Chinese)

30. Lu, C.; Dong, J.C.; Li, B.; Zhou, S.W.; Wang, H.; Wei, Y.G. Selective reduction and enrichment of nickel and iron in limonitic laterite ore with the addition of sodium sulfate. Chin. J. Process. Eng. 2017, 17, 1195-1202. (In Chinese)

31. Tian, C.; He, Z.J.; Zhang, J.H.; Pang, Q.H.; Zhan, W.L.; Liu, J.H. Study on the nickel and iron extraction by direct reduction magnetic separation. Sinter. Pellet 2017, 42, 48-52. (In Chinese)

32. Sun, T.C.; Jiang, M.; Liu, Z.G.; Liu, N.; Xu, C.Y. Research on the effect of additive on selective reduction of the laterite ores with low nickel and high iron content. J. China Univ. Min. Technol. 2013, 42, 838-844. (In Chinese)

33. Li, H.Z.; Guo, H.J. Mechanism study of metal particles agglomeration in semi-fused slag of laterite pellet with carbon. Ferro-Alloy. 2014, 5, 21-27. (In Chinese)

34. Yang, S.; Du, W.G.; Shi, P.Z.; Shangguan, J.; Liu, S.J.; Zhou, C.H.; Chen, P.; Zhang, Q.; Fan, H.L. Mechanistic and kinetic analysis of $\mathrm{Na}_{2} \mathrm{SO}_{4}$-modified laterite decomposition by thermogravimetry coupled with mass spectrometry. PLoS ONE 2016, 11, e0157369. [CrossRef]

35. Zhu, D.Q.; Pan, L.T.; Guo, Z.Q.; Pan, J.; Zhang, F. Utilization of limonitic nickel laterite to produce ferronickel concentrate by the selective reduction-magnetic separation process. Adv. Powder Technol. 2019, 30, 451-460. [CrossRef]

36. Li, G.H.; Rao, M.J.; Jiang, T.; Shi, T.M.; Huang, Q.Q. Reduction roasting magnetic separation mechanisms of nickelferous laterite ore in the presence of sodium salts. Chin. J. Nonferr. Met. 2012, 22, 274-280. (In Chinese)

37. Liu, Z.G.; Sun, T.C.; Wang, X.P. Comparison of direct reduction-magnetic separation process on ferruginous and magnesian laterite ore. Chin. J. Nonferr. Met. 2017, 27, 2173-2177. (In Chinese)

38. Bai, S.J.; Li, C.L.; Fu, X.Y.; Lv, C.; Wen, S.M. Novel method for iron recovery from hazardous iron ore tailing with induced carbothermic reduction-magnetic flocculation separation. Clean Technol. Environ. Policy 2018, 20, 825-837. [CrossRef] 
39. Zinoveev, D.; Grudinsky, P.; Zakumov, A.; Semenov, A.; Panova, M.; Valeev, D.; Kondratiev, A.; Dyubanov, V.; Petelin, A. Influence of $\mathrm{Na} 2 \mathrm{CO} 3$ and $\mathrm{K} 2 \mathrm{CO} 3$ addition on iron grain growth during carbothermic reduction of red mud. Metals 2019, 9, 1313. [CrossRef]

40. Zhu, D.Q.; Chun, T.J.; Pan, J. Mechanism of action of improving reduction on low grade hematite pellets by adding nucleating agent. Chin. J. Process. Eng. 2011, 33, 1325-1330. (In Chinese)

41. Pickles, C.A.; Forster, J.; Elliott, R. Thermodynamic analysis of the carbothermic reduction roastingof a nickeliferous limonitic laterite ore. Miner. Eng. 2014, 65, 33-40. [CrossRef]

42. Guo, Z.Q.; Pan, J.; Zhu, D.Q.; Zhang, F. Green and efficient utilization of waste ferric-oxide desulfurizer to clean waste copper slag by the smelting reduction-sulfurizing process. J. Clean. Prod. 2018, 199, 891-899. [CrossRef]

43. Yang, Y.U.; Niu, F.S.; Gen, W.U. Selectivity flocculation technology present situation of microfine weakly magnetic iron minerals. China Min. Mag. 2008, 17, 91-93. (In Chinese)

44. Chun, T.J.; Ning, C.; Long, H.M.; Li, J.X.; Yang, J.L. Mineralogical characterization of copper slag from tongling nonferrous metals group china. JOM 2016, 68, 2332-2340. [CrossRef]

(C) 2020 by the authors. Licensee MDPI, Basel, Switzerland. This article is an open access article distributed under the terms and conditions of the Creative Commons Attribution (CC BY) license (http://creativecommons.org/licenses/by/4.0/). 